\title{
Erratum to: Who am I and where do I belong? The perception and evaluation of teacher leaders concerning teacher leadership practices and micropolitics in schools
}

\author{
Charlotte Struyve $^{1} \cdot$ Chloé Meredith $^{1}$. \\ Sarah Gielen ${ }^{1}$
}

Published online: 28 March 2015

(C) Springer Science+Business Media Dordrecht 2015

\section{Erratum to: J Educ Change (2014) 15:203-230 DOI 10.1007/s10833-013-9226-5}

We regret to inform readers of the Journal of Educational Change that a recent article published in the Journal contains several similarities to a chapter co-written by the lead author of the article. The relevant article was authored by Struyve, C., Meredith, C., \& Gielen, S. and was entitled "Who am I and where do I belong? The perception and evaluation of teacher leaders concerning teacher leadership practices and micropolitics in schools." Journal of Educational Change, 2014, 15(2), 203-230. doi:10.1007/s10833-013-9226-5.

The previously published chapter appeared in the edited volume Emotion in school: Understanding how the hidden curriculum influences relationships, leadership, teaching and learning and was authored by Struyve, C., \& Kelchtermans, G. (2013). That chapter was entitled "Organizational position and socialprofessional relationships in schools: An exploratory study of teacher leaders' work life in Flanders." The editors of that volume were M. Newberry, A. Gallant \&

The online version of the original article can be found under doi:10.1007/s10833-013-9226-5.

Charlotte Struyve

charlotte.struyve@ppw.kuleuven.be

Chloé Meredith

chloe.meredith@ppw.kuleuven.be

Sarah Gielen

sarah.gielen@ppw.kuleuven.be

1 Centre for Educational Effectiveness and Evaluation, KU Leuven, Dekenstraat 2,

Post Box 3773, 3000 Leuven, Belgium 
P. Riley. The publisher was the Emerald Group Publishing Limited: Bingley, UK (63-80).

After careful and considered review of the content and authorship of this article and with consultation with members of the Editorial Board, the Editor-in-Chief and Managing Editor of the Journal of Educational Change have concluded that, given the nature of the lead authorship in both the published article and the book chapter, this was an instance of self-plagiarism. The article should have not only cited the book chapter by Struyve and Kelchtermans (2013) but should have also contained an explanatory footnote stating much of the material in the article had been previously published in that chapter.

This erratum serves as a public record of this investigation and its findings. We apologize for this unfortunate error.

Dennis Shirley 